\title{
"USO POLÉMICO DA RAZÁO", OU "PAZ PERPÉTUA EM FILOSOFIA"? SOBRE O PENSAMENTO ANTINÓMICO E O PRINCÍPIO DE ANTAGONISMO EM KANT
}

\author{
Leonel Ribeiro dos Santos ${ }^{1}$
}

\begin{abstract}
RESUMO: Fazendo a leitura cruzada de um tardio ensaio de Kant - Anúncio da próxima assinatura de um tratado para a paz perpétua em filosofia (1796) - e da segunda secção do primeiro capítulo da Teoria Transcendental do Método da Crítica da Razão Pura, que leva o título "Disciplina da razão pura em relação ao seu uso polémico", tenta-se identificar e compreender a aparente contradição do programa da crítica kantiana da razão, o qual, se, por um lado, se anuncia com a intenção de resolver os intermináveis conflitos que têm lugar na arena da razão pura, superando o escândalo das aparentes contradiçốes da razão consigo mesma e estabelecendo, enfim, a "paz perpétua em filosofia”, por outro, conduz-se mediante um procedimento dialéctico inspirado na retórica judicial, fazendo apelo a um "uso polémico da razão pura", como sendo a forma mais adequada e, na verdade, segundo o filósofo crítico, a única disponível, para neutralizar, seja as pretensōes do dogmatismo, seja as do cepticismo a propósito das questóes metafísicas. Ao mesmo tempo que a nossa reflexão nos leva a caracterizar a pax philosophica kantiana e as pressupostas homologias entre a solução dos conflitos políticos e a dos conflitos especulativos, chega-se por ela também a reconhecer que toda a filosofia kantiana está originariamente determinada por uma concepção agónica da vida, da sociedade humana, do cosmos, da própria razão.
\end{abstract}

PALAVRAS-CHAVE: Uso polémico da razão. Uso dogmático da razão. Paz perpétua em filosofia. Antinomias. Metáforas biomédicas. Metáforas políticas.

\section{***}

[...] a antinomia da razão pura..., foi isso o que, de início, me despertou do torpor dogmático para a crítica da própria razão, para suprimir o escândalo da aparente contradição da razão consigo mesma.

Immanuel Kant, Carta a Christian Garve, de 21.09.1798 (AA 12: 257-258)

No ano de 1796, Kant publica, numa revista de Berlim (Berlinische Monatschrift, XXVIII, 485-504), um ensaio com o estranho título Anúncio da próxima assinatura de um tratado para a paz perpétua em filosofia (Verkündigung

\footnotetext{
${ }^{1}$ CFUL-Universidade de Lisboa. leonelrs@netcabo.pt
} 
des nahen Abschlusses eines Tractats zum ewigen Frieden in der Philosophie). ${ }^{2} \mathrm{Um}$ tal título parece ser eco do ensaio Para a paz perpétua (Zum ewigen Frieden), publicado no ano anterior, no qual o já septuagenário filósofo expusera o seu programa audacioso para a solução pacífica global dos conflitos nas sociedades humanas, seja no interior de um só Estado, seja no plano das relações entre os diferentes Estados. Do mimetismo do título do novo ensaio poder-seia concluir que o filósofo estende agora à filosofia e aos conflitos entre os filósofos e os sistemas filosóficos solução análoga da que tinha proposto para a solução dos conflitos no domínio político e que, por conseguinte, o topos da "paz perpétua" em política precederia em Kant o topos da "paz perpétua” em filosofia e serviria de modelo para esta.

Mas náo é esse o caso. $\mathrm{Na}$ verdade, o tema da paz perpétua em filosofia expóe-se na obra publicada de Kant muito antes do que o tema da paz perpétua em política. Ou, antes, deveria dizer-se que eles surgem ao mesmo tempo, sendo dado que o filósofo supõe desde o começo uma perfeita homologia entre os dois domínios, deslizando muito naturalmente de um para o outro. Todavia, para melhor nos darmos conta disso, devem ler-se algumas páginas muito pouco lidas e ainda menos atendidas da Crítica da Razão Pura, nomeadamente as da segunda secção do primeiro capítulo da Teoria Transcendental do Método, que leva o título "Disciplina da razão pura por relação ao seu uso polémico" (B 780ss).

O objectivo do presente artigo é, pois, ler o ensaio do ano 1796 a partir do mencionado capítulo da Crítica da Razão Pura e, vice-versa, reinterpretar este capítulo à luz daquele ensaio tardio. Tal leitura cruzada e contrastada de dois textos, que correspondem a momentos muito diferentes de exposição do pensamento kantiano, para além de nos permitir o reconhecimento das homologias que existem entre a solução kantiana das controvérsias filosóficas

\footnotetext{
${ }^{2}$ Verkündigung (AA 08:411-422). O ensaio é uma resposta a J. G. Schlosser, o qual replicara a um outro ensaio de Kant desse mesmo ano (Von einem neuerdings erhobenen vornehmen Ton in der Philosophie, Berlinische Monatschrift, XXVII, 1796, 387-426), onde se procedia à desconstruçáo da interpretaçáa místico-poética do pensamento de Platáo oferecida por aquele pensador "neoplatónico" (assim o designa Kant, sendo um dos primeiros a usar o neologismo!), na Introdução e nas Notas à sua tradução das Cartas de Platáo (Plato’s Briefe über die syrakusanische Staatsrevolution, nebst einer historischen Einleitung und Anmerkungen, Königsberg, 1795). Mas, já no final daquele primeiro ensaio, Kant, passando do registo crítico e irónico ao registo pacificador, deixava indicado o mote que desenvolve neste segundo. As obras de Kant são citadas pela Akademie-Ausgabe (AA), com indicação do respectivo volume e página. A $K r V$ é citada pela paginação da primeira (A) e/ou da segunda (B) ediçấo (em todos os passos citados, as duas ediçôes são idênticas). Nas citaçóes em português da Crítica da Razão Pura, segue-se, por vezes com pequenas alteraçóes, a tradução de Manuela Pinto dos Santos e Alexandre Fradique Morujão (Lisboa: Fundação Calouste Gulbenkian, 2a edição).
} 
e a solução kantiana dos conflitos políticos, pode também esclarecer-nos a respeito da aparente contradiçáo do programa da crítica kantiana da razão, o qual, se, por um lado, se anuncia com a intenção de resolver as intermináveis lutas que têm lugar na "arena" (Kampfplatz) da razão pura, estabelecendo a "paz perpétua em filosofia", por outro lado, conduz-se mediante um procedimento dialéctico, fazendo apelo a um "uso polémico da razáo", como sendo a forma adequada para neutralizar seja as pretensôes do dogmatismo seja as do cepticismo a propósito das questóes metafísicas. Assim, se a releitura daqueles textos nos pode ajudar a caracterizar a originalidade da pax philosophica kantiana, frente a outros programas historicamente conhecidos de pacificação filosófica, nomeadamente, os apresentados por alguns filósofos do Renascimento (tais como Nicolau de Cusa, Giovanni Pico della Mirandola, Agostino Steuco), ela também nos faz reconhecer que a filosofia kantiana é originariamente determinada por uma concepção agónica da razão, do homem e da sociedade humana, da vida, do cosmos. ${ }^{3}$ É isso, com efeito, o que aprendemos do ensaio de 1796: a vida - tanto a de um corpo orgânico, como a da sociedade ou a da razão, que de resto se pensa ela mesma como se fosse um organismo vivo - subsiste na luta de forças antagónicas e, para conservar o seu estado de sanidade, precisa de manter essas forças em proporcionado equilíbrio, quer dizer, em tensão permanente. ${ }^{4}$

\section{I}

O primeiro capítulo da Teoria Transcendental do Método ocupa-se da "Disciplina da razão pura". É o mais longo e sem dúvida um dos mais importantes dessa parte da obra e talvez mesmo um dos mais arcaicos no processo de confecção da obra. No fundo, "disciplina da razão pura” é uma

\footnotetext{
${ }^{3}$ Para dar apenas alguns exemplos maiores desse geral domínio do princípio agónico ou de antagonismo, na filosofia de Kant, seja antes de mais o que se pode colher da leitura do ensaio cosmológico de Kant do ano 1755 , no qual somos convidados a assistir à luta perpétua das forças atractivas contra as forças repulsivas no cosmos, luta que precisamente garante ao cosmos a sua instável estabilidade dinâmica (Allgemeine Naturgeschichte, AA 01:243ss); seja depois o pressuposto do "antagonismo" também dito "insociável socialidade" na antropologia social e política e na filosofia da história kantianas (Idee, AA 08:20), que assegura o dinamismo e o progresso político e moral na história; seja ainda a "luta do bom contra o mau princípio", na antropologia moral e religiosa (Religion, 2. und 3. Stück, AA 06: 57-147).

${ }^{4}$ Neste ensaio, retoma-se a ideia central da comunicação apresentada, numa versão em francês ("Raison polémique, ou paix perpétuelle en Philosophie?”), no III. Multilaterales Kant-Kolloquium (Mainz, 9-13 Oktober 2011), subordinado ao tema Kant und das antinomische Denken / Kant et la pensée antinomique / Kant and antinomical thinking.
} 
outra maneira de dizer a própria empresa crítica da razão. E, segundo Kant, uma tal disciplina torna-se necessária precisamente onde, como na razão pura,

[... se encontra todo um sistema de ilusóes e de enganos bem ligados entre si e reunidos sob princípios comuns, é então preciso uma legislação toda especial, mas negativa, que, sob o nome de disciplina, institua, a partir da natureza da razáo e dos objectos do seu uso puro, como que um sistema da precaução e do exame de si mesma diante do qual nenhuma aparência falsa e sofística possa subsistir, mas deve, ao contrário, revelar-se imediatamente, não obstante todas as razóes com as quais se queira ornamentar. (B 739).

Na primeira secção desse capítulo - "Disciplina da razão pura no seu uso dogmático" -, Kant desenvolve a sua concepção da Matemática e do seu método, confrontando-a com a Filosofia, e chega à conclusão da impossibilidade de transferir os processos próprios da primeira para a segunda. Essa pretensão, que, desde Platáo até aos filósofos modernos, constituiu o expresso desiderato dos metafísicos dogmáticos, longe de servir à Filosofia e ao esclarecimento das suas questóes metafísicas, foi antes, segundo Kant, a fonte das ilusôes, dos equívocos e dos erros que proliferam no campo da filosofia. Quanto ao essencial, o filósofo retoma e reelabora nesse capítulo as teses que sobre o assunto havia exposto num ensaio do ano 1763 (Untersuchung über die Deutlichkeit der Grundsätze der natürlichen Theologie und der Moral). Tais teses são bem conhecidas: Matemática e Filosofia, sendo embora "ciências racionais", são disciplinas absolutamente diferentes, não apenas pelo seu objecto, mas também pelo seu método e pelo respectivo modo de uso da razão. A Matemática é uma ciência racional "por construção de conceitos"; a Filosofia, por sua vez, é um conhecimento racional "por conceitos". A primeira pode examinar e representar o universal in concreto numa intuição a priori que lhe corresponde; a segunda, pelo contrário, tem de considerar sempre o universal in abstracto (por meio de conceitos) e, se as demonstraçóes matemáticas podem ser consideradas verdadeiras demonstraçôes porque penetram na intuição do seu objecto (tornando-o intuível), já as provas filosóficas merecem antes o título de provas acroamáticas (discursivas), e não o de verdadeiras demonstraçóes, pois elas só podem fazer-se mediante meras palavras, isto é, pelo objecto em pensamento ou por conceitos, os quais são sempre abstractos. Não há em Filosofia algo que seja semelhante às definiçóes, aos axiomas e às demonstraçóes que se usam na Matemática e graças aos quais esta ciência tem assegurada a sua certeza (B 758-764). 
Da comparação estabelecida resulta que as proposiçôes filosóficas não podem ter pretensão ao estatuto de verdade e de certeza das proposiçóes matemáticas. Uma tal pretensão, que seduziu vários filósofos modernos, longe de servir a boa causa da razão nas questôes metafísicas, foi antes a fonte de erros e de ilusões que só a crítica da razão pela primeira vez conseguiu descobrir e está em condiçóes de superar. Kant repete-o uma e outra vez:

Não convém de modo nenhum à natureza da Filosofia, sobretudo no campo da razáo pura, engalanar-se com uma aparência dogmática e exibir os títulos e as insígnias da Matemática, ciência a cuja ordem ela não pertence... Isso são vãs pretensões que nunca podem ter sucesso, mas que, pelo contrário, devem comprometer a Filosofia a reflectir sobre o seu desígnio para descobrir as ilusóes de uma razáo que desconhece os seus limites e, por meio de uma clarificação suficiente dos nossos conceitos, conduzir a presunção da especulação a um modesto, mas fundamentado conhecimento de si mesmo". (B 763).

Em alternativa a este método, que tinha a Matemática por seu paradigma e que sonhava poder estabelecer uma ciência dogmática dos supremos objectos metafísicos (Deus, Alma, Mundo), Kant propóe, na segunda secção do capítulo, o que chama o "uso polémico da razão". Mas o que é este uso polémico e de onde provém ele? Quais são as suas possibilidades e limites e que tipo de verdade e de certeza pode ele garantir?

A primeira coisa que deve notar-se é que toda essa secção tem uma relação directa com as secçôes da Dialéctica transcendental, onde Kant apresentara a Antitética da razão pura, falando como se fosse um experimentado estratego:

Estas asserçóes sofísticas abrem pois uma arena dialéctica, onde a vitória pertence ao partido ao qual é permitido tomar a ofensiva, e onde aquele que é forçado a limitar-se a defender-se tem necessariamente de sucumbir. Desse modo, os bravos campeóes, quer eles combatam pela boa ou pela má causa, estáo seguros de levar a coroa da vitória, desde que tenham o cuidado de garantir para si o privilégio de lançar o último ataque e se não forem obrigados a sofrer um novo assalto do adversário. Pensa-se com razão que esta arena foi muitas vezes frequentada até aqui e que um grande número de vitórias nela foram alcançadas de uma e outra parte, mas que, quanto à última, aquela que deveria decidir a questão, sempre se teve o cuidado de que o cavaleiro da boa causa ficasse como único senhor do terreno, interditando ao seu adversário que tomasse de novo as armas. Como juiz imparcial do combate, náo temos de nos preocupar de saber se é pela boa ou má causa que lutam os combatentes, e devemos deixá-los 
terminar entre eles o assunto. Talvez, depois de se terem mutuamente mais cansado do que propriamente ferido, eles reconhecerão por si a vaidade da sua querela e separar-se-áo como bons amigos. (B450-451).

Seguidamente, o filósofo esforça-se por caracterizar o novo método que propóe, como sendo "[...] somente e essencialmente próprio da filosofia transcendental e só nela não prescindível” (nur der Transcendentalphilosophie allein wesentlich eigen... nur in diesem nicht entbehrt - B 452), apontando a semelhança que ele revela com um método céptico, mas sublinhando igualmente a radical diferença em relação ao cepticismo propriamente dito. E insiste que só essa estratégia se adequa à natureza peculiar das asserções da razão pura a respeito dos assuntos metafísicos. Nas suas palavras:

Este método, que consiste em assistir a um combate de asserçóes, ou antes a provocá-lo, não para decidir no fim a favor de um ou de outro partido, mas para investigar se o seu objecto náo seria por acaso uma pura ilusáo, à qual cada um se agarra em vão e onde nada há a ganhar, ainda que não se encontrasse resistência, esta maneira de agir, digo eu, pode ser designada sob o nome de método céptico. Ele é completamente diferente do cepticismo, princípio de uma ignorância artificial e científica, que mina os fundamentos de todo o conhecimento para não lhe deixar em lado nenhum, se possível, nem certeza, nem segurança. O método céptico, com efeito, tende à certeza, procurando descobrir, num tal combate, empreendido de boa fé e conduzido com sensatez dos dois lados... Mas este método céptico só é essencialmente próprio da filosofia transcendental... As asserções transcendentais, que pretendem ser conhecimentos que se estendem para lá do campo de todas as experiências possíveis, não são nem tais que a sua síntese abstracta pudesse ser dada em alguma intuição a priori [como na Matemática], nem feitas de tal maneira que o malentendido pudesse ser descoberto por meio de alguma experiência [como na filosofia experimental]. A razão transcendental não nos fornece, pois, outra pedra-de-toque senáo a que consiste em tentar unir entre si as suas asserçôes e, por conseguinte, em deixá-las antes de tudo lutar umas com as outras livremente e sem obstáculo. (B451-452) .

Trata-se, portanto, de praticar um "método céptico", que não é, todavia, um "cepticismo" e que consiste em levar os contendores a esgrimirem os seus argumentos até à extenuação e, por essa via, a consciencializarem a

5 A mesma ideia é retomada e desenvolvida na secção da Teoria Transcendental do Método, em A 756-757/B784-785. 
ilusão transcendental em que laboram as suas pretensas certezas ou evidências acerca das questôes metafísicas, sejam elas as da tese ou as da antítese. A antitética kantiana responde a três principais questôes: 1) a da identificação das proposiçôes antinómicas da razão e respectiva apresentação numa tópica de antinomias; 2) a da identificação da causa (ou ilusão) de onde provêm as proposiçóes antinómicas; 3 ) a de ver se a razão tem maneira de superar essas antinomias e qual pode ser essa maneira. ${ }^{6}$

Como vimos, o recurso à antitética ou ao método polémico para levar os metafísicos a reconhecer que são vítimas de uma ilusão transcendental justifica-se e impóe-se, segundo Kant, pela natureza própria da Metafísica e das suas questôes, para cujo tratamento os métodos da Lógica e os da Matemática se revelam inadequados. E essa convicção deve ter-lhe estado presente desde a primeira fase de redacção da Crítica da Razão Pura, pois dela dá testemunho a seguinte Reflexão, datável presumivelmente do ano 1772:

$\mathrm{Na}$ crítica da Metafísica pode fazer-se uso de dois métodos. O primeiro consiste em examinar as provas e em procurar os paralogismos ou

${ }^{6} \mathrm{O}$ primeiro que fez uma crítica sistemática da doutrina kantiana das antinomias da razão foi Hegel, o qual reconheceu, apesar de tudo, o seu mérito, ao mesmo tempo que apontou o seu carácter originariamente formal. Segundo Hegel, a antinomia reside na própria realidade e está no cerne do conceito. As principais questóes que se podem formular a propósito das antinomias kantianas são as seguintes: 1) se elas são reais ou apenas aparentes; 2) se as que Kant considera na $\mathrm{KrV}$ - a tópica kantiana das quatro antinomias - esgotam realmente todas as antinomias filosóficas, ou se há outras igualmente pertinentes as quais deveriam ser consideradas e que, de resto, o próprio Kant vem a considerar nas suas outras obras, que têm elas próprias as respectivas Dialécticas: na $K p V$ (as antinomias ou dialéctica da razão prática, entre moralidade e felicidade), na $K d U$ (as antinomias ou dialéctica da razáo estética ou do gosto: entre singularidade e universalidade e entre realismo e idealismo do juízo de gosto; entre idealismo e realismo da finalidade da natureza, entre teleologia da natureza e mecanismo da natureza, entre teleologia da natureza e teleologia moral); 3) se todas as antinomias estáo no mesmo nível e têm a mesma origem, e se admitem idêntico tratamento e têm idêntica soluçấo; 4) qual o verdadeiro peso das antinomias na génese do criticismo kantiano (tendo em conta a carta a Garve, de 21.09.1798, confrontada com outras confissóes do mesmo teor, mas aparentemente não coincidentes com aquela); 5) qual o significado filosófico das antinomias ; 6) se a tópica das antinomias kantianas corresponde ao catálogo das grandes antinomias do pensamento filosófico que se podem identificar na história da filosofia; 6) qual a causa e a origem das antinomias: um erro, um equívoco, uma ilusão transcendental, a desmesura e desproporção entre a razão e a realidade?; 7) qual a coerência do tratamento kantiano das antinomias: será que há uma solidariedade entre as antinomias e que elas constituem um sistema?; 9) a solução kantiana das antinomias é verdadeiramente uma solução, ou dá antes lugar a novas antinomias e controvérsias? Por certo, estas questôes são colocadas aqui não porque as possamos realmente enfrentar, mas apenas para que nos demos conta da amplitude da discussão que o tema exige, a qual não cabe no propósito deste ensaio. Só alguns destes tópicos são considerados na obra de Josef Seifert, Überwindung des Skandals der Vernunft, Die Widerspruchsfreiheit - trotz Kant, Freiburg: Alber, 2001. Veja-se também, do mesmo autor, "Das Antinomienproblem als Grundproblem aller Metaphysik: Kritik der Kritik der reinen Vernunft". Prima Philosophia, v. 2, n. 2, 1989. 
petitiones principii. O segundo consiste em opor a uma prova uma outra e certamente tâo convincente do contrário como aqueloutra. Este último método é o melhor. Sendo dado que os erros das conclusóes metafísicas residem sobretudo no facto de que aquilo que vale apenas a propósito das condições do conhecimento sensível é enunciado a propósito do objecto, então uma prova pode parecer tão rigorosa que dificilmente nos apercebemos de um erro, o qual se descobre muito melhor mediante uma demonstratio oppositi. (Refl. no 4454, AA 17:557).

Da mesma forma, na referida secção da Crítica, lê-se:

Para acabar o processo radicalmente e para satisfação das duas partes, não resta, pois, nenhum meio senão ver que elas podem refutar-se tão bem uma à outra, que acabam por se convencer que disputam por nada, e que uma certa aparência transcendental lhes representou uma realidade ali onde nenhuma existe. (B 529).

Por conseguinte, por "uso polémico da razão pura” Kant entende “[...] a defesa que a razão faz das suas proposiçóes contra as negaçôes dogmáticas das mesmas, não se tratando de saber se as suas asserçóes não poderiam também ser falsas, mas assegurando-se somente de que ninguém alguma vez possa afirmar o contrário com certeza (ou mesmo com uma maior aparência de certeza)" (B 767768). Ao recomendar o uso deste método, o filósofo crítico tem consciência de que nele se trata de uma espécie de prova céptica que os filósofos devem fazer em si mesmos, ainda que ele a represente dramaticamente, na cena de um tribunal, "[...] perante o olhar de um terceiro observador" (in den Augen eines dritten Beobachters) (Refl. 5015; AA 18:61), "[...] enquanto juiz imparcial da luta" (als unparteiischen Kampfrichter) (B 451). Com a argumentação antitética não se pretende, na verdade, produzir nenhum conhecimento do objecto visado nas proposiçóes enunciadas, mas apenas libertar a razão das ilusóes e dos erros que resultam do equívoco onde elas assentam. O objectivo é fazer ver aos metafísicos que uma questão a respeito da qual é possível produzir duas argumentaçóes igualmente convincentes não pode ter verdadeira solução e que, algures, nela se esconde uma ilusão na sua base. Mas, entâo, pode perguntar-se: tudo não passa de um mero jogo que a razão joga consigo mesma, ou que os filósofos, os protagonistas e intérpretes da causa e dos interesses da razão, jogam entre si para, no fim, chegarem a concluir que lutam por nada? Pois, na verdade e no fundo, não há nenhum conflito, nenhuma polémica, nenhuma antinomia, nenhuma antitética na razão ela mesma? 
Tal é, com efeito, a conclusão que Kant repete uma e outra vez, como veremos. Todo o seu trabalho crítico tem em vista esclarecer a natureza aparente das antinomias e assegurar-nos de que não pode haver em geral uma real antitética da razão, e que aquela faculdade a qual deve precisamente ser o tribunal supremo para julgar todos os litígios não pode envolver-se em conflito com ela mesma. Não há que temer nisso um verdadeiro perigo para a razão, porque, como se chegará a reconhecer, propriamente falando, não há nenhuma antitética (B 771), nem nenhuma polémica (B 779,784), no campo da pura razão. Todavia, a uma tal conclusão só se chega mediante o procedimento polémico, jogando com toda a seriedade o jogo das antinomias, esgotando as razôes e argumentos de um e de outro lado. Assim, o método antinómico, da mesma forma que o uso polémico da razão, serve para mostrar que não há e não pode mesmo haver qualquer verdadeira antinomia na razão, que as antinomias somente podem ter por causa alguma ilusão, equívoco ou mal-entendido, o qual basta esclarecer para que deixem de perturbar a paz da razão.

O filósofo faz notar a diferença que existe entre a antinomia cosmológica (referente à ideia de Mundo) e as antinomias teológica (referente à ideia de Deus) e psicológica (referente à ideia de Alma). Na primeira, a antitética tem por base um mal-entendido que consiste em tomar os fenómenos do mundo por coisas-em-si e em pretender que eles possam fornecer uma síntese integral do objecto visado na ideia. Neste caso, uma vez esclarecido o mal-entendido, dissolve-se a antinomia. Porém, no caso da antinomia teológica e psicológica, a razão tem em vista, com as suas proposiçôes, não fenómenos que possam ser dados numa experiência, mas coisas-em-si: isto é, Deus, como ser supremo absolutamente independente do mundo, e a Alma, como substância imaterial e eterna. Neste último caso, escreve Kant,

[...] só haveria uma verdadeira contradição se a razão pura tivesse a dizer do lado da negação alguma coisa que pudesse aproximar-se do fundamento de uma afirmaçáo; porque, no que respeita à crítica dos argumentos da afirmaçáo dogmática, pode-se muito bem aceitá-la ao crítico, sem por isso ter de renunciar a essas proposiçóes, as quais têm ao menos por elas o interesse da razão, interesse que o adversário não pode de modo nenhum invocar. (B769).

Isso quer dizer que, embora a Crítica nos mostre que nada podemos saber no que concerne àquelas realidades (Deus, Alma), não ficamos por isso impedidos de as considerar com legitimidade até mesmo para o uso empírico da razão e, sobretudo, de assumi-las com uma suficiente garantia para o uso 
prático da razão. Podemos até estar plenamente seguros de que ninguém virá alguma vez provar o contrário, e "[...] contra o adversário nós temos à disposiçâo o nosso non liquet, que deve infalivelmente confundi-lo, ainda que não recusemos que ele o revire contra nós" (A742/B770). E Kant conclui, uma vez mais em linguagem de torneio:

Sendo assim, não haveria propriamente antitética da razão pura. Pois a única arena para ela deveria ser procurada no campo da teologia e da psicologia puras; mas este terreno não pode exibir nenhum vencedor munido da sua armadura e de armas que se pudessem temer. Ele só pode exibir-se aí sob o coro de zombarias ou de fanfarronadas das quais podemos fazer troça como de um jogo de crianças. E isso constitui uma observaçáo consoladora, que devolve coragem à razão; pois, de outro modo, sobre que poderia ela apoiar-se, se ela, que é a única chamada a suprimir todos os erros, fosse abalada em si mesma, sem poder esperar nem paz nem posse tranquila. (B 771).

$\mathrm{Na}$ argumentação desenvolvida ao longo de toda a secção, Kant convidanos para um exercício que raia o paradoxo: por um lado, afirma, uma e outra vez, que, propriamente falando, náo existe no campo da razão pura nenhuma verdadeira antitética, nenhum conflito, contradição, antinomia ou mesmo polémica. Por outro lado, reconhece que essa antitética é natural à razão e que ela serve até os fins da natureza no que se refere à razáo e, nesse sentido, uma tal antinomia é verdadeiramente benfazeja e mesmo necessária para que se chegue ao esclarecimento dos verdadeiros interesses da razão e para resolver as antinomias e os conflitos aparentes os quais têm por base algum equívoco ou ilusão. Desse modo, as antinomias excitam a razão, incentivam as suas forças vitais, impedindo-as de que fiquem debilitadas por falta de exercício. $\mathrm{O}$ paradoxo reside, por conseguinte, no facto de que se chega a concluir que não há verdadeira antitética ou polémica na razão pura justamente fazendo um uso polémico e antinómico da razão pura. Mas, assim sendo, o paradoxo revela-se também ele como aparente e resolve-se nestes termos: objectivamente e em si mesma, a razáo não é antinómica (como poderia ela sê-lo em si mesma, se é ela precisamente que tem de decidir todos os conflitos?); mas, subjectivamente considerada, as suas proposiçóes, enquanto são enunciadas e interpretadas pelos filósofos, seja por falta de fundamento, seja por causa de uma qualquer subrepção oculta algures, podem à partida parecer antinómicas e estar em conflito, o que todavia desaparece assim que se submetam essas proposiçóes à prova do método polémico: 
Se olharmos, não ao que acontece, mas ao que razoavelmente deveria acontecer, não deve propriamente existir polémica da razão pura. Com efeito, como podem duas pessoas sustentar uma controvérsia sobre uma coisa a respeito da qual nem uma nem outra podem apresentar a realidade na experiência efectiva ou mesmo somente possível, e a respeito da qual são obrigadas a ir buscar a algum sítio a ideia para dela tirar algo mais do que a ideia, a saber a realidade efectiva do objecto mesmo? Mediante que meio concluirão elas a controvérsia, pois que nenhuma delas pode tornar a sua causa directamente compreensível e certa, mas somente atacar e refutar a causa do adversário? (B 778).

\section{A conclusão segue-se:}

Não há pois propriamente nenhuma polémica no campo da razão pura. Os dois partidos esgrimam no ar e batem-se apenas com as respectivas sombras, porque eles saem dos limites da natureza e vão para uma regiáo onde nada se oferece à garra do seu dogmatismo, nada que eles possam captar e segurar. Eles combateram bem, mas as sombras que eles rasgaram se refazem num fechar de olhos como os heróis de Walhalla, para que possam renovar sempre o prazer de combater assim sem derramamento de sangue. (B 784).

E a tolerância do filósofo crítico pode então expor-se em toda a sua desportiva magnanimidade:

Deixai pois falar o vosso adversário, quando nada mais faz do que falar racionalmente e combatei-o simplesmente com as armas da razão. De resto, não temais quanto à boa causa da razão (o interesse prático), porque essa jamais está em jogo num conflito que é simplesmente especulativo. $\mathrm{O}$ conflito então não revela mais do que uma certa antinomia da razão, a qual, como ela assenta na natureza desta razão, deve necessariamente ser tomada em consideração e examinada. Ele cultiva a razão fazendo-a encarar o seu objecto sob dois pontos de vista, e assim rectifica o seu juízo restringindo-o. O que está aqui em litígio não e a coisa, mas o tom. Pois, ainda que tivésseis de renunciar a falar a linguagem da ciência, resta-vos ainda suficiente para falar a de uma fé sólida, que a razão mais severa autoriza. (B 772).

A verdade que resulta deste uso polémico da razão não é de ordem metafísica, nem de natureza lógica, mas de ordem retórica. Não se trata de demonstrar "a partir de fundamentos objectivos", mas de persuadir as partes em conflito "a partir de fundamentos subjectivos". Trata-se, diz Kant, de 
uma “[...] justificação kat'anthropon, que protege contra todos os prejuízos e proporciona uma propriedade titulada, que não tem que temer nenhumas usurpações estranhas, mesmo se não pode ser demonstrada suficientemente kat'aletheian" (B767). Essa propriedade não é, porém, de teor especulativo e sim de teor prático. O que do uso polémico e antinómico resulta é a certeza de que, se o dogmático não pode pretender à ciência, igualmente o céptico não pode demonstrar que as exigências práticas da razão não têm sentido. Estas ficam, pois, garantidas da dúvida céptica a seu respeito, náo por uma ciência, mas por uma fé prática.

Torna-se assim patente que o jogo das antinomias, longe de prejudicar a razão, antes serve aos seus fins essenciais. E, ao mesmo tempo, percebe-se que o trabalho da crítica da razão não é empreendido por causa do interesse especulativo da razáo, mas por causa do interesse prático da mesma razáo; e precisamente para mostrar que a causa prática da razão, se não pode ser fundada no exercício teorético da mesma, também não pode ser por ele alguma vez contraditada. Pode isso parecer pouco, todavia, é a prova que Kant considera suficiente para moderar a arrogância dos filósofos e os convencer da sua ignorância; é o adequado remédio contra a presunção dogmática e constitui o modo de "[...] pôr termo ao conflito da razão consigo mesma" (den Streit der Vernunft mit sich selbst zu beendigen) (B 785). Assim, a verdadeira intenção e todo o alcance do uso polémico da razão só se revelam, se tivermos em conta que ele está ao serviço do interesse prático da mesma razão. Aí onde não é possível a "explicação" (Erklärung) resta ainda a "defesa" (Vertheidigung) (B 804). Não se trata, por conseguinte, de apresentar fundamentos teóricos para as nossas perspectivas, mas apenas de desmontar as objecçóes que o adversário opóe à possibilidade da liberdade prática. Da luta especulativa da razáo consigo mesma resulta, portanto, um empate. No entanto, desse modo, a razão fica segura de que nada nem ninguém alguma vez pode perturbá-la e pôr em causa o direito às suas pretensôes no plano prático, pois que, de acordo com o filósofo, aí ela está na posse de algo cuja conformidade ao direito náo precisa de provar e do qual, na realidade, também não poderia apresentar prova.

Há que reconhecer a singularidade e a grande ousadia desta abordagem kantiana da Metafísica segundo um método da Retórica, sobretudo quando isso ocorre no âmbito do pensamento moderno, o qual se constituíra em boa medida por reacção contra os procedimentos da Dialéctica e da Retórica dos humanistas e que erigira a Matemática como organon da verdade e critério de certeza e evidência. Mas, ainda assim, Kant podia contar com alguns 
precursores. De facto, muitos conceitos e procedimentos retóricos infiltraram-se imperceptivelmente na nova lógica científica dos Modernos. O próprio Francis Bacon estava disposto a conceder ao genus judiciale da Retórica clássica, caso ele fosse liberto do formalismo e da esterilidade escolares, um lugar no seu novo método, propondo uma espécie de "tópica de todas as questôes controversas", condensadas as respectivas tese e antítese e os argumentos de cada uma destas, naquilo a que chamava Antitheta Rerum 7 . Por outro lado, a Retórica havia sido objecto de particular revalorizaçáo no pensamento dos teólogos da Reforma luterana, como disciplina que habilitava para as controvérsias teológicas. O humanista e teólogo Philipp Melanchthon, para quem "[...] quase toda a Retórica se esgota nos preceitos relativos ao tratamento das controvérsias forenses" ${ }^{8}$, reconhece igualmente o valor dessa disciplina. ${ }^{9}$ E é, sem dúvida, graças a esta reabilitação pedagógica da Retórica que se virá a desenvolver, nos séculos XVII e XVIII, a teologia reformada de controvérsia, de onde poderá ter provindo o conceito kantiano de antitética. ${ }^{10}$ Kant dá prova de estar bem familiarizado com esta literatura e tradição, quando, no mesmo capítulo que estamos comentando, aconselha a maneira de instruir a juventude a respeito das questóes filosóficas. Que se deve fazer? Manter a juventude afastada dessas matérias perigosas, esperando que o seu juízo se torne maduro? $\mathrm{Ou}$, antes,

${ }^{7}$ De dignitate et augmentis scientiarum, lib. VI, cap. III; The Works of Francis Bacon, ed. Spedding/Ellis/ Heath, London, 1858, v. 1, p. 688ss. Como não ver na Antitética kantiana uma réplica do projecto baconiano, se mudarmos as "realidades" pela "razão"?

8 "Tota ferè Rhetorica consumitur in his praeceptis, de tractandis controversiis forensibus." Elementorum rhetorices libri duo. Witebergae, 1582, 28.

${ }^{9}$ Ibidem, 29: "Sed nos tradimus haec praecepta vel ad iudicandas aliorum orationes vel ut etiam instruamus adolescentes ad controversias ... \& ad Ecclesiastica negotia. Nam disputationes Ecclesiasticae magna ex parte similitudinem quandam habent forensium certaminum."

${ }^{10}$ Veja-se: HINSKE, N. Kants Begriff der Antithetik und seine Herkunft aus der Protestantischen Kontroverstheologie des 17. und 18. Jahrhunderts. Archiv für Begriffsgeschichte, v. 16, p. 48-59, 1972. Segundo Hinske, Kant ter-se-ia familiarizado com o conceito de antitética e com o método de controvérsia nos Cursos do teólogo Franz Albert Schulz, leccionados em Maio de 1741 e Agosto de 1744, subordinados ao título Theologia Thetico-Antithetica seu Collegium Thetico-Polemicum et morale (o exemplar dessa obra, existente na Universidade de Königsberg, foi destruído na II Guerra Mundial). Schulz inscreve-se na tradição da teologia reformada de controvérsia, na qual se destacam outros nomes, como o de Paul Anton (Collegium antitheticum universale fundamentale, Halae, 1732) e o de Johan Wilhelm Baier (Collatio doctrinae pontificorum et protestantium, Jenae, 1686). Se, dando fé ao texto citado de Melanchthon, aceitarmos que a fonte comum desta teologia de controvérsia e da antitética é o genus judiciale da Retórica, entăo não é necessário apontar, como o faz Hinske, domínios de proveniência diferentes para os conceitos kantianos de antitética e de antinomia. Enfatiza Hinske, com efeito: "Während der Begriff der Antinomie von Hause aus ein juristischer Begriff ist, stammt der Begriff der Antithetik bei Kant aus dem Umkreis der Theologie." (ibid., p. 56). 
deve-se instruí-la desde cedo numa doutrina considerada verdadeira, para que ela possa na continuação resistir energicamente a toda a persuasão contrária?

Assim expóe o filósofo seu entendimento do que deve ser uma autêntica didáctica filosófica dos assuntos da Filosofia: deve-se sem dúvida instruir a juventude e desde cedo, nas questóes metafísicas. Deve-se fazê-lo, porém, não de uma maneira dogmática, e sim de uma maneira polémica ou crítica. Nas suas palavras:

Aquele que só traz consigo as armas dogmáticas para repelir os ataques do adversário e náo sabe descobrir a dialéctica oculta que se encontra tanto no seu próprio seio como no do antagonista, vê razóes especiosas, que têm a vantagem da novidade, oporem-se a razóes especiosas, que já não têm essa vantagem, antes fazem nascer a suspeita de que se abusou da sua credulidade própria da juventude. Julga que náo pode mostrar melhor ter ultrapassado a disciplina da infância do que rejeitar aquelas sábias advertências e, habituado ao dogmatismo, bebe a longos tragos o veneno que corrompe dogmaticamente os seus princípios. É precisamente o contrário do que aqui se aconselha que deve acontecer no ensino académico, mas simplesmente com o pressuposto de uma instrução sólida na crítica da razáo pura. De facto, para o jovem pôr em prática, tão cedo quanto possível, os princípios desta crítica e reconhecer que são capazes de resolver a maior ilusão dialéctica, é absolutamente necessário dirigir contra a sua própria razão, sem dúvida ainda fraca, mas esclarecida pela crítica, os ataques tăo formidáveis ao dogmatismo e exercitá-la a examinar as vâs afirmaçóes do adversário, ponto por ponto, à luz desses princípios. Não lhe será difícil reduzi-las a pó, e assim cedo sentirá a força de se garantir plenamente contra estas ilusóes nocivas, que acabaráo por perder a seus olhos todo o prestígio. E, embora precisamente os mesmos golpes que arruínam o edifício do inimigo, sejam também funestos à sua própria construçáo especulativa, se alguma vez pensou em erguer uma, está sobre este ponto completamente tranquilo, porque náo tem necessidade alguma de tal construção para nela habitar, visto que diante de si se estende o campo prático, onde pode esperar, com razão, um terreno mais firme para sobre ele construir um sistema racional e salutar. (B 783-784).

Para além de outras importantes instruçôes que carrega, esta página constitui, sem dúvida, uma formulação mais matizada e bem mais exigente do que a vulgar interpretação que se faz daquela conhecida e muito banalizada fórmula kantiana, segundo a qual "não se deve ensinar filosofia, mas a filosofar". 


\section{II}

A secção da Teoria Transcendental do Método, que vimos comentando, está concebida e escrita numa linguagem densa, a qual denuncia uma concepção política da razão em perfeita homologia com uma característica concepção da vida política, como se as condiçôes políticas para o exercício verdadeiramente filosófico (isto é, crítico ou polémico) da razão fossem também as condiçôes para o exercício político da verdadeira e autêntica cidadania. Tais condiçóes dizem-se pelos nomes de liberdade, igualdade, reciprocidade, veracidade e lealdade, os quais fundam a comunidade da razão como um espaço aberto de pensamento livre e de franca comunicação de ideias dos seus cidadãos, os quais têm por si eles mesmos e sem qualquer coacção estranha a competência para dar o seu acordo ou a sua desaprovação. Logo a abrir a secção, encontra-se uma declaração explícita que estabelece a correlação natural e essencial entre a liberdade de filosofar e a filosofia da liberdade, e até mesmo o compromisso entre uma concepção crítica ou polémica da filosofia e uma concepção da vida política que se pode chamar republicana, mesmo se este termo enquanto tal não é utilizado nestas passagens. ${ }^{11}$ Cito:

Em todos os seus empreendimentos deve a razáo submeter-se à crítica e náo pode fazer qualquer ataque à liberdade desta, sem se prejudicar a si mesma e atrair sobre si uma suspeita desfavorável. ... É mesmo sobre esta liberdade que repousa a existência da razão; esta não tem autoridade ditatorial alguma, mas a sua decisão outra coisa náo é que o acordo de cidadãos livres, cada um dos quais deve poder exprimir as suas reservas e mesmo exercer o seu veto sem impedimentos. (B 766-767).

Um pouco mais adiante, a mesma ideia regressa, agora para sublinhar que uma tal liberdade dos cidadáos lhes assegura náo apenas o direito de pensar, mas também o de exprimir as suas ideias nesse espaço público que é a universal razão humana:

A essa liberdade pertence também a de submeter ao juízo público os pensamentos e as dúvidas, que ninguém pode por si mesmo resolver, sem por isso ser reputado um cidadáo turbulento e perigoso. Isto resulta do direito originário da razão humana de náo reconhecer nenhum outro juiz senáo a própria razáo humana universal, onde cada um tem a sua voz; e porque desta

${ }^{11}$ Veja-se: SANTOS, Leonel Ribeiro dos. Kant: da reinvenção do Republicanismo à ideia de uma "República Mundial. Cadernos de Filosofia Alemã, São Paulo, v. 16, p. 13-54 (sobretudo p. 16-19), jul.-dez. 2010. 
deve vir todo o aperfeiçoamento de que o nosso estado é susceptível, um tal direito é sagrado e náo é permitido atentar contra ele. (B 780).

Estamos diante de um tema cheio de sugestóes fecundas, tanto para a caracterização da razão kantiana quanto para o debate actual em torno da racionalidade na esfera pública. Podemos com efeito reconhecer aí, com toda a evidência, os fundamentos de uma razão comunicacional, isto é, de uma prática da razão concebida como exercício honesto e leal de seres racionais livres, iguais e responsáveis, que oferecem uns aos outros as suas perspectivas acerca do mundo num diálogo, disputa ou controvérsia francos, expondo os seus argumentos, apelando à convicção, mas sem poderem realmente ditar e decidir por si mesmos e absolutamente a verdade dos seus pontos de vista. É desse modo que emerge e se constitui a comunidade da razão como um espaço aberto de partilha de convicçóes, argumentadas e discutidas segundo as regras de uma comunidade político-jurídica legalmente fundada, na qual são reconhecidos o direito à liberdade e a igualdade dos cidadãos. Com um só e mesmo gesto, a razão instaura a comunidade política dos homens, ao instituir a comunidade da comunicação racional - de debate, da polémica, do conflito - regida pelas leis do direito universalmente reconhecidas, sendo pressuposta a liberdade partilhada de pensar e de comunicar as próprias ideias. Como tem vindo a ser recentemente reconhecido por vários intérpretes, nessas páginas, Kant propóe um método filosófico do pensar e argumentar que se inspira e orienta pelo paradigma ou conceito de uma razão jurídica (KAULBACH, 1981; SANTOS, 1989, 1994; MARCOS, 1993; BRANDT, 2007). Trata-se, porém, de uma razão jurídica sui generis: a da comunidade política republicana: a razão concebe-se a si mesma e exerce-se verdadeiramente como uma res publica, ao mesmo tempo em que funda e instaura a respublica (SANTOS, 1989, 1994, 2010; HÖFFE, 2001, 2006). Nessa república orgânica da razão, cabe à filosofia, à filosofia crítica, em particular, sobretudo a função judicial. Agora se compreende todo o alcance daquela imagem do tribunal que aparece no Prefácio à primeira edição da obra e que só nesta secção verdadeiramente se explicita:

Pode considerar-se a crítica da razão pura como o verdadeiro tribunal para todas as controvérsias desta faculdade; pois ela nâo está implicada nas controvérsias, na medida em que estas se referem imediatamente aos objectos, mas ela é estabelecida para determinar e julgar os direitos da razão em geral, segundo os princípios da sua instituição primitiva. Sem esta crítica, a razão mantém-se, de certo modo, no estado de natureza e não pode fazer valer ou garantir as suas afirmaçóes e pretensóes a não ser 
pela guerra. A crítica, pelo contrário, que extrai todas as decisóes das regras fundamentais da sua própria instituição, cuja autoridade ninguém pode pôr em dúvida, proporciona-nos a tranquilidade de um estado legal em que não nos é permitido tratar o nosso diferendo a não ser mediante um processo. O que no primeiro caso póe termo às querelas é uma vitória de que se vangloriam ambas as partes e à qual segue, a maioria das vezes, uma paz mal assegurada, imposta pela intervençáo de uma autoridade superior; no segundo caso, porém, a sentença, porque toca agora a fonte das discussóes, deve conduzir a uma paz perpétua. Os conflitos intermináveis de uma razão simplesmente dogmática obrigam-nos também a procurar finalmente repouso numa crítica dessa própria razão e numa legislação que nela se funda. Tal como Hobbes afirma, o estado de natureza é um estado de violência e de prepotência e devemos necessariamente abandoná-lo para nos submetermos à coacção das leis, que não limita a nossa liberdade senão para que possa conciliar-se com a liberdade de qualquer outro e, desse modo, com o bem comum. (B 779-780).

Esta passagem esclarece-nos a propósito de um ponto importante para o nosso assunto. Se tomarmos a sério a lição da analogia, vê-se que a filosofia crítica está para a instituição da razão como o contrato social o está para a constituição do Estado: tanto uma como o outro operam a passagem do estado de natureza - onde, segundo a concepção hobbesiana, que, nesse ponto, Kant partilha, à falta de uma lei comum reconhecida por todos, governa o arbitrário poder de cada qual e onde os conflitos são decididos pela guerra - ao estado civil, onde a lei e a liberdade são reconhecidas por todos e a todos e onde os conflitos são conduzidos de acordo com as regras legais de um processo judicial. Na república da razão, da mesma forma que na república civil, com a instauração do estado civil, não cessarão por certo os conflitos e as controvérsias, mas doravante estes deverão ser resolvidos por um procedimento judiciário, segundo as leis da razão comum e no respeito formal das condiçóes de liberdade, de igualdade e de reciprocidade entre os protagonistas.

Por certo, podemos perguntar-nos se Kant estaria realmente consciente do facto de que a sua filosofia estava assim construída no ambiente de um paradigma político-jurídico bem característico e até mesmo revolucionário, na época em que é exposto. Se disso tinha consciência, por que não declara ele abertamente aos seus leitores qual o modelo político que de modo subreptício assim lhes inculca? Porque lhes dá, por essa forma sub-reptícia, uma determinada concepção da vida política, quando eles pensam estar apenas a 
ser instruídos a propósito de questóes de metafísica teorética e dos elevados assuntos da razão pura?

Cremos poder dizer que, com tanto de astúcia quanto de senso pedagógico, ao expor assim a sua filosofia conforme o paradigma de uma constituição política bem determinada - a republicana -, e sem que os seus leitores disso se apercebessem, Kant opera neles a revolução da razão, isto é, convida-os para uma completa alteração da maneira de pensar, conduzindoos sem violência não apenas para o único ponto de vista a partir do qual é possível apreciar e resolver as antinomias metafísicas em conflito, na arena da razáo, mas lhes propondo igualmente uma forma de existência política que é a única capaz de resolver as antinomias da sociedade humana e que, ao mesmo tempo, está de acordo com a condição dos seres humanos racionais e livres: uma forma de existência política, em suma, na qual a liberdade é pressuposto necessário e condição de possibilidade, não apenas da dignidade humana, mas também do exercício filosófico da razão, exercício este que é do próprio interesse da república, visto que, como o filósofo reiteradamente o diz, sem o exame rigoroso e as objecçôes da filosofia, os governantes náo poderão estar suficientemente esclarecidos a propósito daquilo mesmo que lhes pode ser vantajoso ou prejudicial (Zum ewigen Frieden, AA 08:369; Streit der Fakultäten, AA 07:35).

Deve sublinhar-se a extraordinária novidade da proposta kantiana de uma racionalidade polémica - de controvérsia e de conflito - em alternativa a uma racionalidade dogmática; por conseguinte, a abertura a uma razão dialógica e comunicacional, num espaço público de livre apresentação de opiniōes e de confronto argumentativo de diferentes visôes do mundo, nenhuma das quais apresenta condiçôes para se afirmar e provar como absoluta. A razão revelase assim como comunidade aberta de racionalidade e de leal discussão entre iguais, uma racionalidade que é pensada e exposta segundo o paradigma de uma razão retórico-jurídica, em alternativa a uma racionalidade dogmática ou doutrinária, a qual tivesse por paradigma tanto os pressupostos da Lógica como os procedimentos da Matemática. Kant apresenta-se assim como precursor de uma verdadeira razão comunicacional e até de uma racionalidade retórica, isto é, de uma racionalidade que se debate com antíteses e antinomias, num campo povoado por diferentes perspectivas, que são indecidíveis absolutamente e de uma vez por todas para qualquer dos lados pela mera invocação de regras lógicas formais ou de supostas provas objectivas, que, de resto, não podem apresentar. Contudo, o efeito desta estratégia kantiana de racionalidade 
polémica e retórica não é a promoção do indiferentismo filosófico, que tornaria equivalentes pela irrelevância todas as posiçóes, mas sim a positiva neutralização da pretensão dessas perspectivas a valerem como absolutas e verdadeiras, excluindo as outras, sem com isso eliminar a continuação da dialéctica entre elas, o que é mesmo considerado como um exercício necessário e salutar para a razão. Todavia, uma vez esclarecida a natureza dessa dialéctica, pela crítica da razão, ela já não pode mais prejudicar a razão e o seu verdadeiro interesse, que, de acordo com o filósofo, não é especulativo, mas sim ético.

\section{III}

Na secção da Teoria Transcendental do Método, que temos estado a comentar, encontra-se uma observação na qual Kant diz que até mesmo o negativo, real ou aparente - como é, para a razão, o caso das antinomias - deve, em última instância, servir para algo bom e poder ser usado ao serviço de boas causas (B 771). Isso faz supor uma concepção teleológica e biológica da razão, a qual é reforçada por outras imagens, como, por exemplo, a da inoculação do veneno de um partido na doença do outro, a saber, o inocular as dúvidas do cepticismo nas pretensôes desmesuradas do dogmatismo e assim controlá-los um pelo outro. O filósofo exprimia aí o desígnio de "[...] erigir um sistema saudável" ("ein heilsames System zu errichten" - B784) e de encontrar um "[...] remédio contra a presunção dogmática” (Heilmittel wider den dogmatischen Eigendünkel' - B 785). Eis as suas palavras:

Tudo o que a própria natureza ordena é bom para qualquer fim. Até mesmo os venenos servem para vencer outros venenos que se formam nos nossos próprios humores, e por conseguinte não devem estar ausentes numa colecçáo completa de remédios (farmácia). As objecçôes contra a segurança e a presunção da nossa razão puramente especulativa são elas mesmas fornecidas pela natureza mesma desta razão, e por conseguinte elas devem ter a sua boa destinação, um objectivo que não se deve desdenhar. (B771-772).

Este passo permite-nos a transição para o ensaio de 1796, onde se trata sobretudo da vida e da boa saúde da razão. Todo o ensaio se desenvolve com efeito no ambiente de uma metafórica biomédica, a qual se articula e funde com a metafórica política, a qual vai expressa na eloquência do seu título. A vida é aí descrita como o equilíbrio entre forças antagónicas, de acção e de repulsão, entre as "forças estimulantes" da vida (reizenden Kräfte / Lebensreiz) e o "poder vital” (Lebensvermögen) que reage sobre aquelas. É assim 
que "[...] se considera são um homem no qual um estímulo proporcionado produz um efeito que não é nem demasiado forte nem demasiado fraco" 12 . Assumindo a função de um verdadeiro médico da razão, o filósofo crítico considera que a propensão que se tem para raciocinar filosoficamente e para, por causa da filosofia, se envolver com outros em disputas, querelas, litígios e brigas e até mesmo para se organizar, como se fosse numa guerra declarada de escola contra escola, defendendo cada qual a sua própria filosofia com paixão, como se de um exército contra outro se tratasse, uma tal "propensão" (Hang) ou, antes, uma tal "impulsão" (Drang), longe de deverem considerarse como sintomas de uma doença mortal, devem antes ser tidas por algo que foi disposto pela benfeitora e sábia natureza, com vista a evitar a putrefacção e a morte do corpo vivo da razão, morte e apodrecimento que inevitavelmente lhe adviriam, caso lhe viesse a faltar o exercício em tensão das suas forças vitais. Pode, pois, dizer-se que a filosofia tem verdadeiramente como seu "efeito físico" o status salubritatis da razão (Verkündigung AA 08:414). Tratase, bem entendido, da filosofia crítica, a qual se exerce, como vimos, no uso polémico e nas antinomias; não da filosofia dogmática, a qual antes favorece a sonolência e o sono da razão; não também da filosofia céptica, que desiste de verdadeira pesquisa, e nem dessa espécie de filosofia doxológica, que Kant chama o moderatismo, a qual procura a conciliação superficial das doutrinas, sendo como esses remédios que são tidos como bons para todas as doenças, mas que não curam nenhuma.

De imediato, somos reenviados da linguagem da medicina para o ambiente da metafórica política. E o filósofo fala então da efectiva conexão que existe entre a filosofia crítica e um permanente estado de paz em filosofia, declarando, no mesmo sentido das teses defendidas na Crítica, que a filosofia crítica é aquela que

[...] abre perspectivas para uma paz perpétua entre os filósofos, por um lado, mediante a fraqueza das provas teoréticas e, por outro, mediante a força dos fundamentos práticos da assunção de seus princípios; para uma paz que tem ainda a vantagem de manter sempre activas as forças do sujeito mediante os ataques que na aparência o ameaçam e, desta maneira, ela toma a seu cargo a

12 "Das Leben aber in der Einwirkung reizender Kräfte (den Lebensreiz) und dem Vermögen auf reizenden Kräfte zurückzuwirken (dem Lebensvermögen) setzt und denjenigen Menschen gesund nennt, in welchem ein proportionirlicher Reiz weder eine übermässige noch eine gar zu geringe Wirkung hervorbringt... " (08:413). Na mesma linha, lê-se numa passagem da Anthropologie: "A vida (do animal), porém, como também já os médicos o notaram, é um contínuo jogo de antagonismo de ambos [do prazer e da dor]" ("Leben aber (des Thiers) ist, wie auch schon die Ärzte angemerkt haben, ein continuirliches Spiel des Antagonismus von beiden [Vergnügen und Schmerz]"). (AA 07:231). 
intenção da natureza com vista à animação constante dessas forças, evitando, graças à filosofia, o sono da morte. (Verkündigung, AA 08:416).

A filosofia crítica é, por conseguinte, o meio de que se serve uma natureza que procede teleologicamente para animar sem cessar a razão, de modo a que esta não deixe de ter em vista o fim final da humanidade. Desse modo se vê que a constituição conflitual da razão não é um estado de guerra, mas é antes a maneira de garantir "[...] a preponderância dos fundamentos práticos sobre os contra-fundamentos teóricos, podendo assegurar a paz” (Verkündigung, 08:417). E é dessa forma que o filósofo pensa estar em condiçóes de poder anunciar a "assinatura próxima de um tratado de paz perpétua em filosofia", convencido que está de que, se subsiste ainda algum conflito a propósito do que diz a filosofia enquanto doutrina da sabedoria, isso se deve a um simples mal-entendido ou à confusão dos princípios morais práticos com os princípios teoréticos, pois somente os primeiros podem dar-nos alguma informação respeitante ao suprassensível e nenhuma objecção teorética digna de consideração poderá ser-lhes oposta (Verkündigung, 08:419).

Neste ensaio tardio, é talvez ainda mais explícito do que o era na Crítica o quanto e o como é o interesse prático que estimula a razão para o próprio uso polémico da razão especulativa, na esperança de poder por esse modo neutralizar, uma vez por todas, as objecçóes que poderiam provir dali contra a possibilidade e a realidade prática do mundo inteligível e da liberdade, e assim assegurando uma paz perpétua à razão. Todavia, este estado de paz não significa a morte da filosofia ou o seu esgotamento pelo abafar das questóes metafísicas. Pelo contrário, tais questôes persistem e elas não deixarão de assaltar a razão, não podendo esta evitá-las ou descartá-las, devendo antes e sempre de novo levá-las perante o tribunal da razão crítica. Mas o debate, o conflito, a controvérsia não podem mais perturbar seriamente a paz da razão. Seja na Crítica, seja no ensaio do ano 1796, Kant permanece fiel à sua tese: é precisamente graças à polémica - ao uso polémico da razão - que a razão garante os seus direitos à liberdade moral com tudo o que esta convoca. A libertas philosophandi, isto é, o uso livre e público da razão, é a condição para a philosophia libertatis. Mas pode igualmente dizer-se que é a exigência da liberdade prática que requer a liberdade para o uso especulativo e crítico da razão, a fim de que esta possa discutir sem constrangimentos exteriores as suas questóes e, para que tal seja verdadeiramente efectivo, é preciso que seja também garantida a liberdade de pensar e de exprimir as ideias ou as dúvidas 
dos filósofos ou dos cidadãos da comunidade civil da razão, o que, por seu turno, exige o reconhecimento da efectiva liberdade civil ou política. Fica assim patente o íntimo compromisso que existe entre a filosofia crítica e a filosofia política kantianas, entre o são regime da razão e o são regime das coisas humanas - o status salubritatis rationis e o status salubritatis reipublicae - e até que ponto são originariamente políticas tanto a ideia kantiana de razão quanto a ideia kantiana de filosofia e do seu exercício.

SANTOS, Leonel Ribeiro dos. "Polemical use of reason" or "perpetual peace in philosophy"? On antinomical thought and the principle of antagonism in Kant's philosophy: Trans/ Form/Ação, Marília, v. 37, p. 93-116, 2014. Edição Especial.

\begin{abstract}
We compare Kant's essay Announcement of the forthcoming signing of a treaty for perpetual peace in philosophy with the second section in chapter one of the Transcendental Theory of Method of the Critique of Pure Reason ("Discipline of pure reason in respect of its polemical use"), and try to identify and understand the seeming contradiction of Kant's program. On the one hand Kant intends to solve the unending conflicts in the arena of pure reason by overcoming the apparent contradictions of reason with itself, and thus at last establishing "perpetual peace in philosophy". On the other hand he follows a dialectical procedure inspired by judicial rhetoric, appealing to a "polemical use of pure reason" as the most adequate and indeed the only way possible of neutralizing the pretensions of both dogmatism and scepticism. Our reflection leads us to characterize Kant's pax philosophica and the pressuposed homologies between the solution of political and speculative conflicts. We also recognize that Kantian philosophy is originally determined by an agonic conception of life, human society, the cosmos, and reason itself.
\end{abstract}

KEYWORDS: Polemical use of reason. Dogmatic use of reason. Perpetual Peace in Philosophy. Antinomies. Biomedical metaphors. Political metaphors.

\title{
REFERÊNCIAS
}

BACON, Francis. De dignitate et augmentis scientiarum. In: The Works of Francis Bacon. Ed. by James Spedding, Robert Leslie Ellis and Douglas D. Heath. London: Logman, 1858. v. 1.

BRANDT, Reinhard. Kritik der reinen Vernunft: Der Gerichtshof. In: Die Bestimmung des Menschen bei Kant. Hamburg: Meiner, 2007. Kap.7.

HERNÁNDEZ MARCOS, Maximiliano. La Crítica de la razón pura como proceso civil: sobre la interpretación jurídica de la filosofía trascendental de I. Kant. Salamanca: Universidad de Salamanca, 1993. 
HINSKE, Norbert. Kant's Begriff der Antithetik und seine Herkunft aus der Protestantischen Kontorverstheologie des 17. und 18. Jahrhunderts. Archiv für Begriffsgeschichte, v. 16, p. 48-59, 1972.

HÖFFE, Ottfried. The Critique of pure reason: a cosmo-political reading. In: Kant's cosmopolitan theory of law and peace. Cambridge: Cambridge University Press, 2006. Chap. 12. Traduzido do alemão: Königliche Völker. Zu Kants Kosmopolitischer Rechts- und Friedenstheorie. Frankfurt.a.M.: Suhrkamp, 2001.

KAULBACH, Friedrich. Philosophie als Wissenschaft. Eine Anleitung zum Studium von Kants Kritik der reinen Vernunft. Hildesheim: Gerstenberg, 1981.(10. Vorlesung: "Transzendentale Dialektik als Logik der Entscheidung zwischen streitenden Weltperspektiven: Juridischer Vernunftbegriff').

MELANCHTHON, Philipp. Elementorum rhetorices libri duo. Witebergae, 1582.

SANTOS, Leonel Ribeiro dos. A instauração republicana da razão: aradigmas políticojurídicos do pensar kantiano. In: Metáforas da razáo ou economia poética do pensar kantiano. Lisboa: FLUL, 1989; Lisboa: Fundação Calouste Gulbenkian/JNICT, 1994. Parte 2, cap. VII.

. Kant: da reinvenção do Republicanismo à ideia de uma "República Mundial". Cadernos de Filosofia Alemã, São Paulo, v. 16, p. 13-54, jul.-dez. 2010.

SEIFERT, Josef. Überwindgung des Skandals der reinen Vernunft. Die Widerspruchsfreiheittrotz Kant. Freiburg: Alber, 2001.

Das Antinomienproblem als Grundproblem aller Metaphysik: Kritik der Kritik der reinen Vernunft. Prima Philosophia, v. 2, n. 2, 1989. 
SANTOS, L. R. 